\title{
MEMORIALIZATION OF THE FIRST WORLD WAR IN THE LANDSCAPE OF THE JULIAN ALPS
}

\author{
Jaka Repič \\ Department of Ethnology and Cultural Anthropology \\ Faculty of Arts \\ University of Ljubljana, Slovenia \\ email: jaka.repic@ff.uni-lj.si
}

\begin{abstract}
This article addresses issues of past and ongoing memorialization processes and heritage construction of the First World War, integrated into the landscapes of the Julian Alps in Slovenia. According to Nicholas Saunders, military histories usually consider landscapes to be inert, static, empty, and self-evident backdrops to military action as well as subsequent practices of memorialization. However, many anthropologists, geographers, and archaeologists have noted that landscapes cannot be separated from human experiences, but are part of a world of relationships, memories, and histories.

This article explores connections between the military and post-military landscape and memorialization of the First World War, established through landscape features, experiences of the landscape, and commemorations by institutions that engage in interpretation and heritage production. Various landscape attributes, such as paths, monuments, and memorial places, are being (re)constructed as tourist and hiking destinations, and the narratives attached to these places are integrated into national and local political discourses and commemorations. Drawing on recent anthropological discussions on the perception of landscape, this article focuses on the Isonzo Front and particularly its background as palimpsest of overlapping spatial changes as well as memorialization and appropriations of heritage in the Alpine landscape.
\end{abstract}

Keywords: Alps, First World War, heritage, memorialization, military landscape

\section{INTRODUCTION}

The First World War was a turning point for European society and also globally in many aspects. Scholars from various disciplines have studied the war and its diverse and lasting implications, but scholarly discussions of the war were particularly dominated by studies focusing on history, political science, and the military. Anthropology, however, has until recently had relatively little 
to say about the First World War. However, as Nicholas Saunders points out, there are some important aspects to be addressed through the anthropological perspective.

The First World War remains ambiguously 'recent' in European imagination - hovering on the boundary between 'living' oral history, military history, museology, and issues of tourism and cultural heritage. ... Anthropologically informed it [research] offers, at the very least, the opportunity to investigate: a) a conflict hitherto known mainly from historical sources, b) the reconstitution of post-war landscapes, and c) the evolution of commemorative materialities, both large and small (i.e. large monument to small personal souvenir). (Saunders 2013: 20)

This article is part of the research project Heritage of the First World War: Representations and Reinterpretation (see Jezernik \& Fikfak 2018). Theoretically it is based on recent archaeological, geographical, and, particularly, anthropological literature on the environment and landscape, and empirically on historical and ethnographic research in the Bohinj region in Slovenia. It examines the impact of the First World War on landscapes along the Isonzo Front and its hinterlands, particularly in the Bohinj region in Slovenia. It addresses war and postwar landscapes as a medium of memorialization practices, heritage production, as well as locality and identity formation. Hence, it examines landscape as palimpsests of diverse environmental practices and materialities imbued with meanings and memories related to the First World War. Moreover, it also addresses connections between landscape, memories, and identification processes, established through commemoration and heritage production, or personal experiences and perceptions of the environment. Various environmental attributes that were created and integrated into the landscape during and after the First World War - such as paths, fortresses, dugout trenches and caverns, graveyards, monuments, and remains of weapons, and spent and unexploded ammunition - are today still being (re)constructed and reimagined as memorial places, museum artifacts, thematic trails, and tourist and hiking paths. Some of these attributes are also reconstructed as historically defining places for particular localities, with local, institutional, and political narratives referring to memories of war (Bajuk Senčar 2018; Kozorog 2018; Kravanja 2018). These attributes are continuously appropriated by local and national heritage institutions and are constitutive to the landscape of the First World War in the Alps in Slovenia and Italy.

The article starts by presenting various approaches related to landscape studies and highlights the concept of war and military landscapes. It then describes the landscape changes due to military technology and warfare on the 
front and in the Bohinj region as the supply hinterland. Landscape changes include topographical changes that occurred as direct involvement of the military technology and combat on the front and in the hinterland, such as new railways, deforestation, mountain paths, cableways, and military barracks. It also includes changes in the social, economic, and political landscape of the region altered due to war, new industries, and particularly the large number of local people drafted into the armies, and thousands of soldiers from the AustroHungarian Empire coming, leaving, and residing in the area during the war.

Finally, the article examines postwar reconstitution of the landscape and memorialization of the First World War and the production of war heritage in the Bohinj and Isonzo Front regions in the Slovenian Alps. Postwar landscapes continued to change from military landscapes into landscapes of memories and heritage. Graveyards and monuments were constructed, and places previously occupied by the military were destroyed, abandoned, left to decay, or turned into places of memorial and commemorative tourism - and recently into institutional heritage production. The First World War architecturally, technologically, and even morphologically altered and marked the landscapes along the Isonzo Front and its hinterland, and environmental features such as graveyards, monuments, or mountain paths still reconnect people's spatial experiences with memories of war and postwar landscape reconstitution.

\section{ADDRESSING WAR AND MILITARY LANDSCAPES}

The landscape is far from a novel concept in anthropology, archaeology, or geography. Christopher Tilley observed that scholars have had a long interest in the relationships between people and the landscape, but that usually this relationship was conceived rather narrowly as an "environmental milieu", and focused on functional and supposedly adaptive parameters, with matters such as population levels, resource "ceiling", and environmental constraints. In this naturalist or ecological view, the landscape was seen as something inert, a neutral backdrop to activity and a means for material production. Recent anthropological, geographical, and archaeological literature usually addresses the landscape from two dominant perspectives, often labeled either as phenomenological or structural approaches. Phenomenological approaches try to understand people's experiences of the environment, whereas structural approaches "seek to unearth how landscape and the environment have been shaped by political, social, economic and historical forces" (Árnason 2010: 80). Structural approaches focus on political, social, cultural, and economic forces that historically shape or change landscapes and environments, but fail to 
explain how these forces shape daily experience of and in these environments. Quite contrarily, phenomenological approaches explore the ways in which people experience and understand the world, starting from direct experiences of, and engagement with, the environment (e.g. Ingold 1993; Tilley 1994; cf. Ingold \& Vergunst 2008).

Denis Cosgrove and Stephen Daniels posit that the concept of landscape is highly ideological (Cosgrove \& Daniels 1988; see also Cosgrove 1984). In their book titled The Iconography of Landscape, which was highly influential for further discussions on landscape, they write: "A landscape is a cultural image, a pictorial way of representing, structuring or symbolizing surroundings" (Daniels \& Cosgrove 1988: 1). According to them, landscape is not an environment but a literary, artistic, or political symbolization and representation of the environment. Cosgrove writes that "the idea of landscape came to denote the artistic and literary representation of the visible world, the scenery... viewed by a spectator" (1984: 9). Similarly, Tim Cresswell writes: "We do not live in landscapes - we look at them" (2004: 11). For Cosgrove, landscape is a way of seeing, a cultural image with pictorial, literary or material representations on the ground, which are created and read. "Representations of landscape have the potential to both obscure and articulate lived experience" (Tilley 1994: 25). In this sense, landscape representations of memories and heritage are highly complex, often even contested, because they are open to social constructions and political reinterpretations.

However, it is important to note that some scholars disputed such an approach because it implies inherent distinctions and separateness between external reality and human perception and conceptualization of it. Tim Ingold has rejected the division between the "inner and outer world - respectively of mind and matter, meaning and substance", and instead proposed focusing on the dwelling perspective: "The landscape is the world as it is known to those who dwell therein, who inhabit its places and journey along the paths connecting them" (Ingold 1993: 156; cf. Lund \& Benediktsson 2010).

Christopher Tilley also rejects the notion of landscape being merely a form of mental representation and cognition, and points to the interplay between materialities and perception: "The locales in a landscape may be natural features such as bays or inlets on a coastline or high points, or humanly created places such as monuments or settlements" (Tilley 1994: 25). Moreover, many scholars stress the processual quality of the landscape and address its temporality and changeability (cf. Bender 1993, 2001a, 2001b, 2002; Tilley 1994, 2012; Hirsch 1995; Massey 2006). The landscape they posit is in a process of morphological, archaeological, and conceptual changes, a "pattern of activities 'collapsed' into an array of features" (Ingold 1993: 166). Human activities are not merely imprinted 
onto the landscape, they are continuously incorporated into it: "Landscapes ... are part of the world of movement, relationships, memories and histories" (Bender 2001b: 76; cf. Feld \& Basso 1996; Bender \& Winer 2001). Hence, experiences of contemporary inhabitants are always grounded in a historically modified and modifying environment. Ingold has pointed out that people and the environment are mutually constitutive and change-inducing components of the same world: "the landscape is never complete: neither 'built' nor 'unbuilt,' it is perpetually under construction. ... The forms of the landscape are not preprepared for people to live in - not by nature nor by human hands - for it is in the very process of dwelling that these forms are constituted" (Ingold 2000: 193).

The contemporary world was thoroughly shaped through wars and military technology. Particularly experiences and memories of the First World War have deeply influenced the formation of European societies, heritage politics, and practices of memorialization. Nicholas Saunders addressed war landscapes and particularly the Western Front as a symbolic landscape for our time: "human experiences of the Western Front landscapes between 1914 and 1918 were deeply formative ... (and) impressed vivid imagery onto individual and collective memories" (Saunders 2001a: 37).

War and military landscapes are socially and historically constructed landscapes comprised of physical places with an array of materialities such as natural features, buildings, paths, roads, infrastructures, monuments, memorial places, and places of commemorative events. Military actions were incorporated into the landscape as much as landscape features affected the practices and experiences of mountain warfare (cf. Keller 2009). Memorialization of the First World War has been an ongoing process of spatial incorporation of war and other military activities as well as memorial, commemorative, and heritage-making practices into the landscape by diverse local, national, and international actors and institutions.

Rachel Woodward broadly defines military landscapes as "landscapes which reflect in their constitution and expression the imprint of military activities" (2014: 41). I broaden this view by encompassing an entire palimpsest of mundane and military materialities and activities as well as postwar reconstitution and incorporation of the remnants and memorials of the war. War memorials, monuments, architectural and technological remains, and the spatial practices and politics of memorialization profoundly change the perception and imagination of the landscapes, local and national histories, and heritage. The Isonzo Front and its geographical backgrounds have been outfitted with service paths, military remnants, graveyards, and monuments, as well as with numerous accounts and narratives of battles, human misery, and achievements. 
War and military landscape received relatively little attention in anthropology, unlike in military studies, history, geography, and partly also archaeology. Traditionally, military studies examined the landscape through the utility of the environment in military strategies. Military fronts have mainly been researched in terms of military history - as a "place of stasis and attrition, human misery, suffering, death and eventual victory" (Saunders 2001a: 37). Usually such an approach sees "landscape as inert - an empty backdrop to military action" (ibid.). However, Woodward (2014) lists several studies in which war and the military landscape were addressed in terms of identity construction, social memories, and heritage production. For example, Ross Wilson (2011) shows how naming of places and landscape features among the British soldiers on the Western Front made possible a sense of place and construction of their military identities. After the war, the military landscape was turned into a landscape of mourning, commemorations, tourism, and heritage production (see Morris 1997; Iles 2003; Winter 1998 [1995], 2006; Saunders 2001b, 2002). For example, David W. Lloyd (1998) describes the development of postwar tourism and pilgrimage to military sites, and Snezhana Dimitrova (2005) addresses the commemorations, memorial sites, and monuments of the First World War Bulgarian soldiers as landscape of memories and forgetting, which also played a role in national identity construction.

Saunders proposed exploring the First World War fronts not just as a "series of battlefields, but as a palimpsest of overlapping, multi-vocal landscapes" (Saunders 2001a: 37). In line with recent discussions of landscape in anthropology, which stress its processual quality, in which human actions are integrated into the landscape not as layers to be uncovered by archaeological studies, but as always in a process of change, and subjected to constant reinterpretations and representations, I address war and military landscapes as ongoing processes, still affecting lives, memories, politics, and heritage production a century later.

\section{THE MILITARY LANDSCAPE IN BOHINJ AND THE WIDER ISONZO FRONT}

During the First World War the Bohinj region was an important supply hinterland for parts of the Isonzo Front. Bohinj is a basin in the Upper Carniola region in northwestern Slovenia; it is oriented east-west and bounded to the west by the Julian Alps and periglacial Lake Bohinj. From the lake basin two inhabited valleys, the Upper Bohinj Valley and Lower Bohinj Valley, open towards the east. The lake is fed by the Savica River with Savica Falls as the spring. From the lake on the east end, the Bohinjka River flows along the lower valley, the 
Nomenj Basin, and through a narrow canyon almost closing the valley to the east. Lake Bohinj lies at an elevation of 526 meters, and the highest mountains surrounding it are well over 2,000 meters high.

At the start of the First World War, Bohinj's population of less than five thousand people was dispersed among several small villages and the industrial and administrative town of Bohinjska Bistrica. Historically, the economy of the valley predominantly relied on iron mining, forestry, and agriculture. The most important segment of agriculture was cattle farming, especially for cheese and other diary production, and, to a lesser extent, meat and leather products. The valley is surrounded by medium- and high-elevation pastures where transhumant grazing was practiced (see Repič 2014). Hence before the war the mountainous landscape was already traversed by various paths leading to forests, pastures, and hunting lands. On some of the mountain plateaus, archaeological finds show temporary settlements as early as the seventh to third centuries BC. In the Middle Ages, the people of Bohinj started using the mountain plateaus, located between a few hours and a full day of walking from the valley, for transhumant summer pasturing. Before the war most of these mountain plateaus were high-elevation pastures surrounded by forests and high mountains. On some of them there were settlements with wooden buildings and cattle enclosures for temporary cattle herding and cheese production during the summer months.

Starting in the late nineteenth century, Bohinj also developed tourism infrastructure and services, initially through mountain guiding and hiking. "Mountain guides discovered and built new mountain paths and participated in the construction of mountain lodges" (Bajuk Senčar 2005: 76). Since then, tourism became a steadily growing economic segment that, despite coming to a halt during the First World War, again proliferated after the war, also with memorial and commemoration tourism.

The local population's relations with the environment changed with the start of the First World War, which had a lasting impact on the society, economy, and landscape. The military front in the mountains above Bohinj was established in spring 1915, but the war already demanded heavy provisions from the civil population, such as labor and agricultural produce. In addition, men that were not employed in critical infrastructure were drafted into the Austrian army to serve on the Russian front. Bohinj was not excluded from this. In July 1914, when military mobilization started, about two hundred men were drafted from Bohinj into the Austrian army to serve on the Eastern Front.

On May 23, 1915, Italy declared war on Austria-Hungary and a six-hundredkilometer Austrian-Italian military front was established, stretching from the Stelvio Pass close to the borders between Austria, Switzerland, and Italy, 
extending across Trentino and South Tirol, the Dolomites, the Carnic and Julian Alps, and all the way to the Adriatic coast along the Isonzo Valley. The Isonzo Front was opened with the Italian offensive in June 1915, which aimed to capture the Isonzo Valley and Karst Plateau, and cross the mountain ranges. It stretched for approximately ninety kilometers from Mount Rombon as the northern extreme and along the Isonzo Valley to the Isonzo estuary in the Adriatic. From the beginning, the Italian army failed to penetrate the AustrianHungarian defenses even though the Italian army initially greatly outnumbered the Austrian-Hungarian army. Hence the Isonzo Front was mostly static for the next two and a half years until October 1917, when, in the Twelfth Battle of the Isonzo or the Battle of Caporetto, the Austrian and German armies managed to break into the Italian defenses and pushed the Italian army into the Venetian lowlands. However, for almost two and a half years the front was fortified on the mountain ranges, making good defensive positions possible on both sides. That meant that the mountain warfare, as violent as it was, was also very static, not unlike the Western Front, because the soldiers of both armies were fortified in the high mountains and shielded in excavated caverns and stone fortifications. This static warfare nevertheless resulted in high numbers of dead and wounded, with estimates between seven hundred thousand and over a million casualties on the Isonzo Front alone.

The military division of the Isonzo Front was organized between the frontline and the hinterland, which was also heavily impacted due to the mountainous warfare. The Bohinj region was a supply hinterland to parts of the Isonzo Front, particularly to the Mount Krn battlefields in the high mountains above the Isonzo Valley. As a hinterland to the front, Bohinj played an important role in military supply. The main infrastructure such as the railroad was heavily protected and new infrastructure was developed for military purposes. The military presence and governance were a ubiquitous fact of life in the valley during the war. Movement of the local population in Bohinj was restricted, and residents had to provide travel documents when entering or leaving the region. On the other hand, thousands of military personnel traveled through the valley or stayed there before they moved to the mountain front. The Bohinj Valley on the one hand lost many young men that were drafted into the army, but on the other hand thousands of soldiers of the Austrian army were settled in military camps, hotels, and even with locals. The army had military training camps next to the settlements and also brought Russian prisoners from the Eastern Front. They were settled in prison camps in Ukanc to work at military and infrastructure projects.

The locals had to provide the army with provisions, but some locals were also employed to work for the military; for example, on the narrow-gauge railway. 
Others worked in industries that thrived because of military demands, such as dairy and cheese production, mining, and forestry, or they worked in shops or hotels. A local starting point for the military supply chain was the town of Bohinjska Bistrica. The railroad to Bohinj and the tunnel from Bohinjska Bistrica to Tolmin in the Isonzo Valley was already built in 1906 as the main rail line between Prague and Trieste on the Adriatic Sea, passing through Villach, Jesenice, Bohinj, Tolmin, and Gorica/Gorizia. During the war the Bohinj railway was the main supply line of the Austrian army at the Mount Krn battlefield, used to transport military material, clothes, weapons, food, and building material to Bohinj and from there to the mountain frontline. Large warehouses were built in Bohinjska Bistrica, which were later transformed into a timber factory. From there, a road and later a narrow-gauge railroad were built, leading towards Ukanc just below the Komna Plateau. Cargo was transported there and to the mountains, at first on foot and with horse-drawn carriages, and later on most of the cargo was transported by rail and cableways. The local population and horses were used for help with the transport. In the fall of 1915, the Austrian army organized the building of the narrow-gauge railway to Ukanc and the base of the mountain (see Budkovič 1999: 35-45). Initially, this railway relied on horses that pulled carriages. In 1917, with the increasing demands for transportation of food, fuel, ammunition, weapons, mail, sanitation material, clothing, and building material to the front, the Austrian army built a power plant on the Savica River to power cargo trains on this railway. From Ukanc, the cargo was transported to the mountains on newly built mule tracks and by means of cargo cableways.

Ukanc, previously a pastureland west of the lake and close to the base of the mountains, was turned into a military site. Russian prisoners were settled in Ukanc to perform most of the infrastructure work, especially building paths and roads and digging trenches. Previous pasturelands in Ukanc were transformed into military camps, storage places, and training sites. From Ukanc, mountain paths and mule tracks as well as cableways were built leading all the way to the Komna Plateau at around 1,500 meters in elevation. At Komna, a highland pasture, the Austrian army built a camp for soldiers and officers with a military field hospital, officers' quarters, barracks for soldiers, warehouses, cargo cableways, a chapel, and a graveyard. From Komna the military built mountain paths and cableways that led all the way across the Bogatin Pass and toward Mount Krn to the frontlines. The largest cableway started in Ukanc and ascended to Komna, over the Bogatin Pass to the Peski Ridge, and down to the Tolmin Valley (the military system of cableways was described by Budkovič 1999: 51-77). Just before the Bogatin Pass, at an elevation of almost two thousand meters, another military camp was built, and reserve defensive positions were fortified in case the Italian army broke through the Mount Krn front. 
Before the war, there was practically no substantial infrastructure apart from pasture shelters and mountain paths. New paths and mule tracks, cableways, military camps, a cemetery, and dumping grounds thus profoundly changed the mountainous landscape. There was daily traffic of soldiers and workers (often Russian prisoners) climbing or descending the mountains along these paths and transporting all kinds of materials, weapons, ammunition, and bodies of dead soldiers. Altogether over two hundred kilometers of cableways were built with the capacity to transport several hundred tons of equipment and supply per day.

Similar large-scale infrastructure work was carried out above Kranjska Gora, north of the Bohinj region, where a cableway led to the Vršič Pass (1,611 m) and descended to the Trenta Valley of the Upper Isonzo Valley. In addition, mostly through the work of Russian prisoners, a mountain supply road was built, leading from Kranjska Gora to the Vršič Pass and descending to the source of the Isonzo River along the Trenta Valley. This is still the main connecting road between Upper Carniola and the Upper Isonzo Valley. During its construction, workers were exposed to harsh winter conditions and avalanches. On March 8, 1916, a large avalanche destroyed one of the work camps and killed around two to three hundred Russian prisoners working on the road, and up to eighty Austrian guards. This was the deadliest avalanche in Slovenia to date. Later in the same year, the Russian prisoners built a memorial chapel (the Russian Chapel) next to the road, which has remained a site of changing commemoration practices and even political rituals at the national level. However, the Russian prisoners that worked on the road did not only die in the avalanche. Most of them, an estimated eight to ten thousand, died due to severe conditions, diseases, cold, and exhaustion.

The landscapes of the Bohinj region in Slovenia and other regions of the Isonzo Front were shaped by military involvement and post-military reconstitution into the landscape of memory and heritage. The First World War frontlines were predominantly static ones, but the war nevertheless utterly changed the landscapes of the front and its hinterland due to the technological, engineering, architectural, and social impact of the military and its supply and production chain. Frontlines were inscribed into the environment with trenches, fortresses, caverns, blasted ground, leftover unexploded ordnance, remnants of military equipment, and human remains. The hinterland was also changed into an industrial landscape of supply roads, railways, factories, and military and prison camps. In contrast to large parts of the Western Front that occupied a previously mostly inhabited or cultivated environment, and changed the idyllic rural landscape into a wasteland of "endless craters, barbed wire (and) devastated buildings" (Saunders 2001a: 38), the Alpine frontlines were set up in an uninhabited mountainous environment with a mountain landscape. 


\section{POSTWAR MEMORIAL LANDSCAPES AND HERITAGE PRODUCTION}

The social and spatial devastation at the end of the war, in 1918, was beyond comparison with anything in history. The dead, missing, and wounded were counted in the millions, and many of the survivors were ill, crippled, or mentally affected. The landscapes of the front and its hinterland were also devastated or changed by industrialization and infrastructure. Trees were cut on a massive scale and used for construction timber and firewood at the camps and on the front. Roads, a railroad, a power plant, mountain paths, and cargo cableways were constructed as entire regions were militarized. At the front, land and life were destroyed, and the landscape acquired new meanings through military actions and human experiences of war. In the Alps, the soldiers on the front took up positions in caverns, trenches, and fortresses. They were not only targeted by enemy bombs, but also endangered by the harsh mountain environment, cold temperatures, and deadly avalanches in the winter.

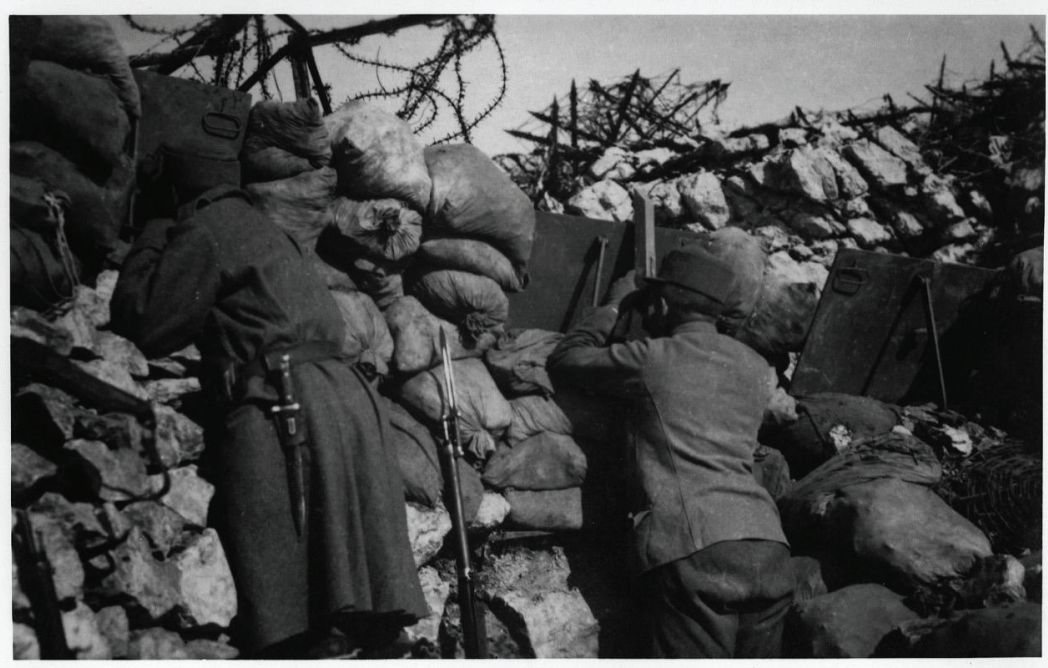

Figure 1. Austro-Hungarian positions on Mount Batognica - the first frontline. Courtesy of the National Museum of Contemporary History, Slovenia. 


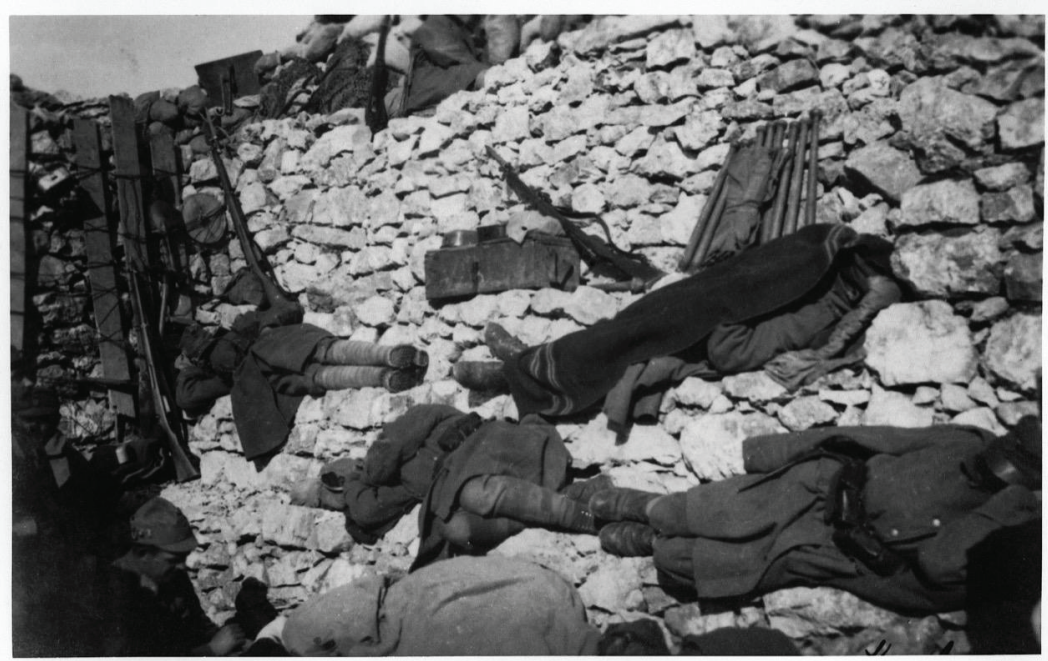

Figure 2. Krn Mountains, Batognica - resting in a trench on the first frontline; the soldiers' firearms and cold weapons are well discerned in the photograph. Courtesy of the National Museum of Contemporary History, Slovenia.

The immediate landscape in which they lived, fought, and often died, utterly characterized their perceptions of the landscape, experiences of war, and memories and commemoration practices after the war. During the war, military landscapes were represented to the public through photographs, films, drawings, and paintings, but they were also portrayed in newspaper reports, personal diaries, memoirs, novels, war poetry, and art. "The human cost of these new landscapes was described day by day ... in memoirs and regimental war diaries" (Saunders 2002, 2003). In the narratives and art, war landscapes were often portrayed as something otherworldly, barren, desolate, lifeless, and poignant.

After the war, the landscape stood as a silent reminder to the memories of the war. It was filled with remnants of industrialized warfare, ranging from trenches, dugouts, battlefield markings, monuments, spent shells, shrapnel, and unexploded ordnance to body parts. The abandoned fronts were composed of tombs for the missing, graveyards of unknown soldiers, and places for returning and pilgrimage. In France, some areas were so devastated they were considered too dangerous to reoccupy. There were also tensions between farmers that wished to return to their land and those that wanted the devastated land and the ruins to remain as a memorial site to the war and the dead (see Saunders 2001a: 41-42). War-torn landscapes were seen as memorial places per se. 
Figure 3. Soldiers wearing white covers to increase camouflage in snow in the high mountains of the Soča battlefield. Courtesy of the National Museum of Contemporary History, Slovenia.

Along the Isonzo Front, battles took place in the mountains, but the

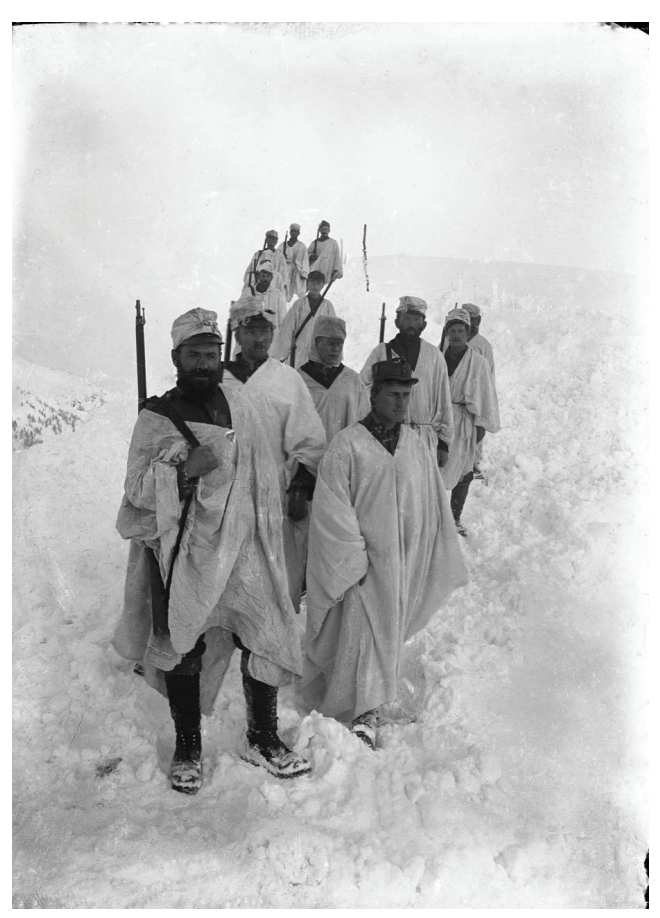
locals nevertheless collected a great amount of military artifacts and eventually engaged in representations and reinterpretations of the war through local museums and military collections (see Kravanja 2018).

Military constructions were dismantled or abandoned, or their function was changed: buildings were turned into mountain lodges, monuments were built, and open-air museums were established. Some of the infrastructure, such as paths and cableways, was used for new purposes after the war. The Bohinj narrow-gauge railway was used for two more years after the war for local transport and even transporting tourists before it was dismantled. Specific places such as graveyards and caverns were turned into memorial or heritage sites or tourism infrastructure.

Part of the cableways between Savica Falls and the Komna Plateau was reconstructed and is still operational. Some of the houses on the Komna Plateau were razed to the ground and some are still preserved as mountain cottages. On the Komna Plateau, the wartime cemetery was later dug up, and the bones of the fallen soldiers were collected and reinterred in a pyramid-shaped memorial ossuary. Pathways and mountain roads for transporting artillery and soldiers were later used as hiking paths. During the interwar period, these landscapes became places of returning and reconstruction of broken houses and lives, or places of pilgrimage that survivors returned to or relatives of the victims visited. 


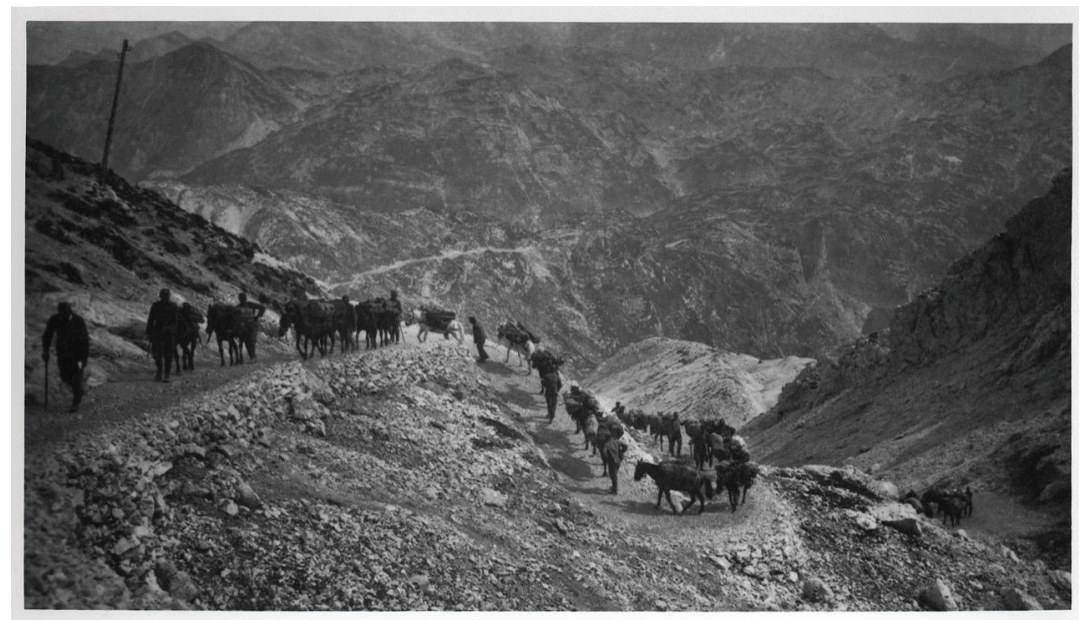

Figure 4. Austro-Hungarian soldiers on their way to the frontline in the Krn Mountains: a view from Peski towards Lemež and Vogel. Courtesy of the National Museum of Contemporary History, Slovenia.

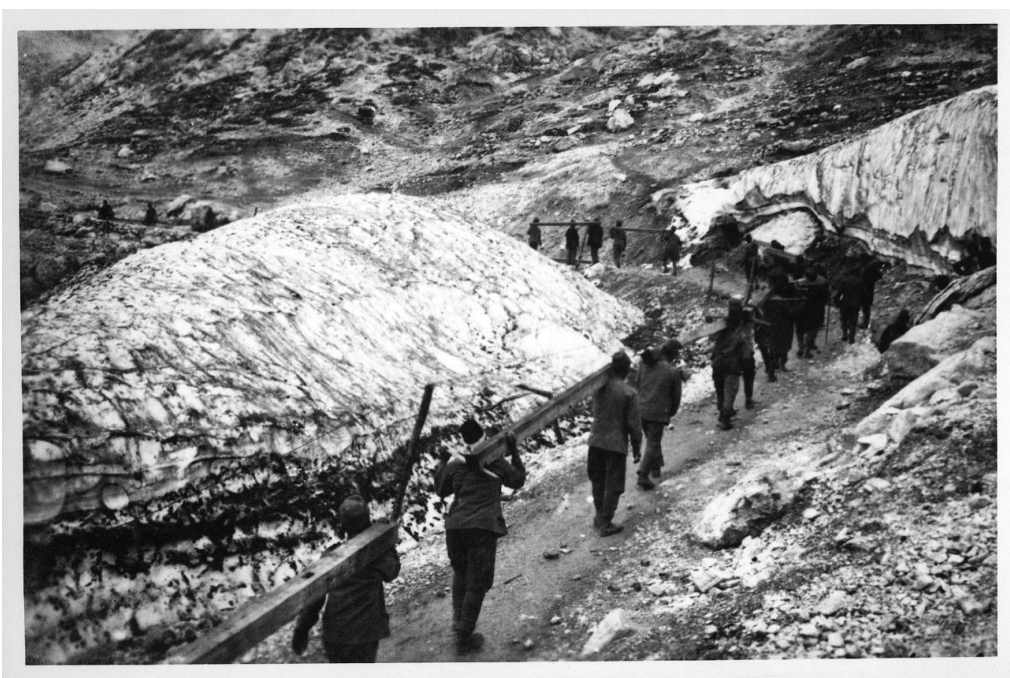

Figure 5. Austro-Hungarian soldiers transporting building materials on their way to Planina na Kraju, in the Krn Mountains above Bohinj. Courtesy of the National Museum of Contemporary History, Slovenia. 


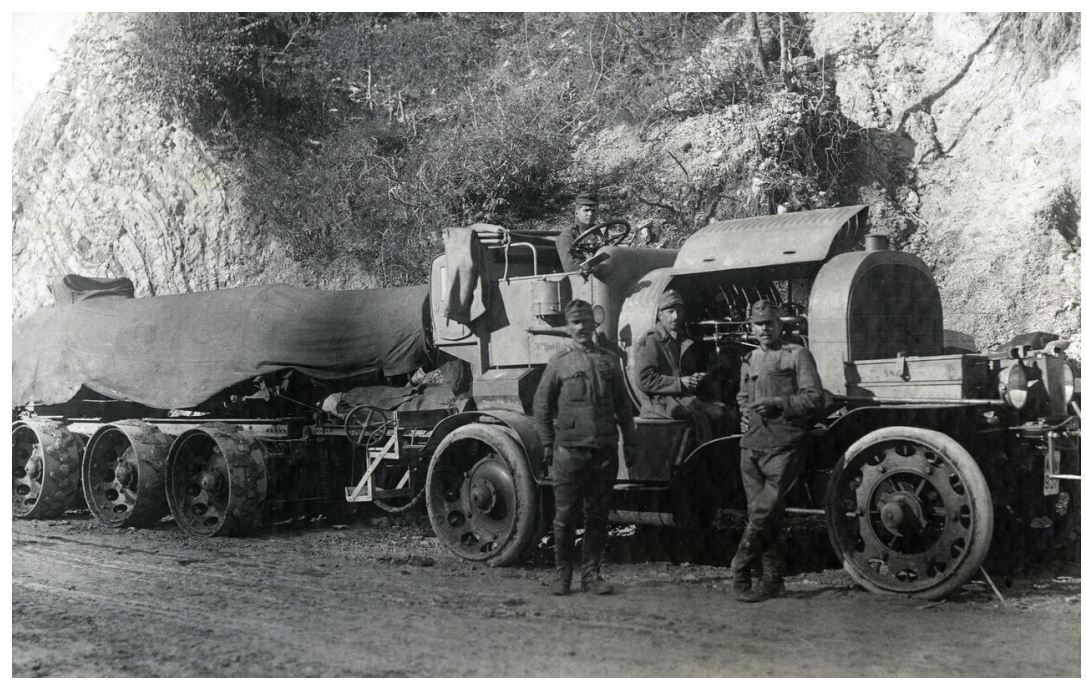

Figure 6. Many new soldiers, plenty of equipment and arms had to be transported to Posočje for the needs of the joint Austro-Hungarian and German offensive. Transportation of the Austro-Hungarian $38 \mathrm{~cm}$ mortar on the road towards Podbrdo. Courtesy of the National Museum of Contemporary History, Slovenia.

With time and the Second World War, these landscapes were largely forgotten. Several monuments were erected, but many memorial places, such as graveyards, mountain fortresses, or caverns, were only much later transformed into tourist destinations, sites for archaeological research, or collections of military remains. Politics and practices of remembering and forgetting are seen in the changing landscape: battlefield remains were removed, reconstructed, or moved into institutions such as local museums. Saunders writes (2001a: 45) that the rediscovery and remembrance of the First World War in France started with the fiftieth anniversary of the war.

In the Isonzo Front region, the social memory of the First World War was diminished because of the importance of the Second World War for communist Yugoslavia (Luthar 2011). Most visible are numerous war graveyards, scattered along the Isonzo Front. Mostly in the Austrian part memorial graveyards were built, whereas on the Italian side ossuaries are common. Unlike in France, in the Kingdom of the Serbs, Croats, and Slovenes dead soldiers were not overly commemorated because it was difficult to glorify the military defeat. In Bohinj, several monuments and memorials dedicated to the victims of the First World War were created, mainly because of the local victims. There are also several 
memorial sites, such as graveyards in Ukanc and Bohinjska Bistrica, and the aforementioned cemetery on the Komna Plateau, which was removed a few years after the war. Larger projects of the First World War heritage production only started in the 1990s and proliferated with Slovenian accession to the European Union. In the recent past, there have been ongoing processes of heritage production (see Fikfak \& Bajuk Senčar 2015; Bajuk Senčar 2018). Monuments and memorial places became places of tourism, commemoration, and political contestation. "The increase in tourists began to change both the physical and cultural landscapes in terms of re-presenting First World War sites to a late twentieth-century audience" (Saunders 2001a: 45).

The Isonzo Front has been turned into a symbolic landscape of memories and heritage. In 1990 the Kobarid Museum was established to represent heritage of the First World War along with the Isonzo Front. In 2000 the Slovenian government established the Walk of Peace in the Soča Region Foundation to preserve the heritage of the Isonzo Front. This turned into an international project, which aims to change the once war-torn places into places of memories. It is a remembrance route crossing the Slovenian-Italian border that connects sites of cultural heritage (graveyards, chapels, forts, outdoor museums, etc.) of the First World War between the Alps and the Adriatic. As an example of the heritage production, the Walk of Peace was submitted to UNESCO's Tentative Lists in 2016 with the following assertion:

The First World War has left a permanent imprint on that territory. Until today, abundant material heritage has been preserved along the former front line: fortresses, trenches, observation posts, transportation ways, cabins, natural and man-made caves, military cemeteries, charnel houses, chapels, monuments and memorials.

Over a span of a hundred years the remembrance of the "years of horror" has changed its perspective from the military to commemorative and peace-fostering collective and transnational remembrance. (UNESCO Tentative Lists)

In Bohinj there were also some local incentives to connect Bohinj to the First World War heritage as the hinterland to the Isonzo Front. These include memorial sites, museum exhibitions on the war, and memorial tourism. In 2007 a thematic trail, Supply Hinterland for the Krn Battlefield, was established as a memorial hiking route along the remnants of the war in the valley and in the mountains. In this sense, ongoing heritage making, memorialization of the war, commemoration events, and tourism are still transforming the landscape of war and memory. 


\section{CONCLUSION}

This article addresses how the landscape of the Isonzo Front and the Julian Alps in Slovenia was changed during and after the First World War, and explores how ongoing memorialization and heritage construction of the war is integrated into the landscapes of the front and its hinterland, particularly in the Bohinj region. The landscape of the wider Isonzo Front and its hinterland was radically transformed during the war, but also continued to change after the war. Some of its new features were disassembled or left to decay, some were reused in different contexts, and some remained either as hidden testaments or as evident places of memory and commemorations.

The wartime and postwar landscape does not merely consist of a set of historical layers dating back to the war and various postwar human activities and natural decay or overgrowth. Instead it is constantly changing and integrates diverse materialities ranging from various natural and architectural formations, paths, and other spatial features to imaginaries of places, all of which are maintained in narratives and daily or memorial practices in this particular environment. In this sense, one can speak of the array of diverse environmental attributes, both natural and manmade in their formation, which were created and integrated into the landscape during and after the First World War. Today, these materialities contribute to possible memorialization and heritage construction. Nicholas Saunders writes: "Often unbearably poignant, areas of the Isonzo in northeast Italy, the Ypres Salient in Belgium, and the Somme and Verdun in France, became prime examples of the social construction of landscape ..., which have implicated the lives of a succession of people since 1914" (Saunders 2004: 7).

Monuments, mountain paths, fortresses, trenches, caverns, railroads, armor, weapons, unexploded ordnance, graveyards, monuments, letters, diaries, clothing, human remains, and other remnants of the war have been material reminders of the war for the past century. Military involvement is still symbolically and archaeologically evident in environmental features, landscape representations, commemorative practices, and the daily life of the local residents. The landscape and diverse artifacts still stand as a memorial to the war, but are open to ongoing reinterpretations by individuals and particularly local and national institutions involved in heritage construction and commemoration practices. 


\section{ACKNOWLEDGEMENTS}

The article was written within the project Heritage of the First World War: Representations and Reinterpretations (J6-7173), which was financially supported by the Slovenian Research Agency.

\section{REFERENCES}

Árnason, Arnar 2010. Grief Paves the Way. In: Karl Benediktsson \& Katrín Anna Lund (eds.) Conversations with Landscape. Farnham, UK: Ashgate, pp. 79-96.

Bajuk Senčar, Tatiana 2005. Kultura turizma: Antropološki pogled na razvoj Bohinja. [Culture of Tourism: Anthropological Perspective on the Development of Bohinj.] Ljubljana: Založba ZRC.

Bajuk Senčar, Tatiana 2018. From the Hinterland: Commemorating the Centenary of World War I in Bohinj. Folklore: Electronic Journal of Folklore, Vol. 73, pp. 47-66. https://doi.org/10.7592/FEJF2018.73.bajuk.

Bender, Barbara 1993. Introduction: Landscape - Meaning and Action. In: Barbara Bender (ed.) Landscape: Politics and Perspectives. Oxford: Berg, pp. 1-17.

Bender, Barbara 2001a. Introduction. In: Barbara Bender \& Margot Winer (eds.) Contested Landscapes: Movement, Exile and Place. Oxford: Berg, pp. 1-18.

Bender, Barbara 2001b. Landscapes on-the-Move. Journal of Social Archaeology, Vol. 1, No. 1, pp. 75-89. http://dx.doi.org/10.1177/146960530100100106.

Bender, Barbara 2002. Time and Landscape. Current Anthropology, Vol. 43, No. S4, pp. 103-112. http://dx.doi.org/10.1086/339561.

Bender, Barbara \& Winer, Margot (eds.) 2001. Contested Landscapes: Movement, Exile and Place. Oxford: Berg.

Budkovič, Tomaž 1999. Bohinj 1914-1918: Med fronto in zaledjem. [Bohinj 1914-1918: Between the Frontline and the Hinterland.] Klagenfurt: Mohorjeva družba.

Cosgrove, Denis 1984. Social Formation and Symbolic Landscape. London: Croom Helm.

Cosgrove, Denis \& Daniels, Stephen (eds.) 1988. The Iconography of Landscape. Cambridge: Cambridge University Press.

Cresswell, Tim 2004. Place: A Short Introduction. Oxford: Blackwell.

Daniels, Stephen \& Cosgrove, Denis 1988. Introduction: Iconography and Landscape. In: Denis Cosgrove \& Stephen Daniels (eds.) The Iconography of Landscape. Cambridge: Cambridge University Press, pp. 1-10.

Dimitrova, Snezhana 2005. "Taming the Death": The Culture of Death (1915-1918) and Its Remembering and Commemorating through First World War Soldier Monuments in Bulgaria (1917-44). Social History, Vol. 30, No. 2, pp. 175-194. Available at https://www.tandfonline.com/toc/rshi20/30/2?nav=tocList, last accessed on 12 September 2018.

Feld, Steven \& Basso, Keith H. 1996. Senses of Place. Santa Fe: School of American Research Press. 
Fikfak, Jurij \& Bajuk Senčar, Tatiana 2015. Triglavski narodni park: Akterji, strategije, problemi, rešitve. [Triglav National Park: Actors, Strategies, Problems, Solutions.] Traditiones, Vol. 44, No. 1, pp. 7-27. http:// doi.org/10.3986/Traditio2015440101.

Hirsch, Eric 1995. Introduction. Landscape: Between Place and Space. In: Eric Hirsch \& Michael O'Hanlon (eds.) The Anthropology of Landscape: Perspectives on Place and Space. Oxford: Clarendon Press, pp. 1-30.

Iles, Jennifer 2003. Death, Leisure and Landscape: British Tourism to the Western Front. In: Mark Dorrian \& Gillian Rose (eds.) Deterritorialisations... Revisioning Landscapes and Politics. London: Black Dog Publishing, pp. 234-243.

Ingold, Tim 1993. The Temporality of the Landscape. World Archaeology, Vol. 25, No. 2, pp. 152-174. http://dx.doi.org/10.1080/00438243.1993.9980235.

Ingold, Tim 2000. The Perception of the Environment: Essays on Livelihood, Dwelling and Skill. London: Routledge.

Ingold, Tim \& Vergunst, Jo Lee (eds.) 2008. Ways of Walking: Ethnography and Practice on Foot. Aldershot, UK: Ashgate.

Jezernik, Božidar \& Fikfak, Jurij (eds.) 2018. Cultural Heritage of the Great War. Traditiones, Vol. 47, No. 1. DOI: 10.3986/Traditio20184701.

Keller, Tait 2009. The Mountains Roar: The Alps during the Great War. Environmental History, Vol. 14, No. 2, pp. 253-274. http://dx.doi.org/10.1093/envhis/14.2.253.

Kozorog, Miha 2018. Knowledge of Place in Three Popular Music Representations of the First World War. Folklore: Electronic Journal of Folklore, Vol. 73, pp. 67-94. https://doi.org/10.7592/FEJF2018.73.kozorog.

Kravanja, Boštjan 2018. Learning by Collecting: Amateur Collectors and Their Shifting Positions in Isonzo Front Heritagization and Tourism Adaptation. Folklore: Electronic Journal of Folklore, Vol. 73, pp. 95-116. https://doi.org/10.7592/ FEJF2018.73.kravanja.

Lloyd, David W. 1998. Battlefield Tourism: Pilgrimage and the Commemoration of the Great War in Britain, Australia and Canada, 1919-1939. Oxford: Berg.

Lund, Katrín Anna \& Benediktsson, Karl 2010. Introduction: Starting a Conversation with Landscape. In: Karl Benediktsson \& Katrín Anna Lund (eds.) Conversations with Landscape. Farnham, UK: Ashgate, pp. 1-12.

Luthar, Oto 2011. "Dokler nas smrt ne loči”: Moderna spominska pokrajina in nacionalizacija kolektivnega spomina po prvi svetovni vojni. [Until Death Do Us Part: Modern Memorial Landscape and Nationalization of Collective Memory of the First World War.] In: Tanja Petrović (ed.) Politike reprezentacije v Jugovzhodni Evropi na prelomu stoletij. Ljubljana: Založba ZRC, pp. 173-199.

Massey, Doreen 2006. Landscape as a Provocation: Reflections on Moving Mountains. Journal of Material Culture, Vol. 11, No. 1-2, pp. 33-48. Available at http:// journals.sagepub.com/toc/mcua/11/1-2, last accessed on 13 September 2018.

Morris, Mandy S. 1997. Gardens 'For Ever England': Landscape, Identity and the First World War British Cemeteries on the Western Front. Ecumene, Vol. 4, No. 4, pp. 410-434. Available at https://www.jstor.org/stable/i40178201, last accessed on 13 September 2018.

Repič, Jaka 2014. Gibanje kot prostorske prakse in ekonomske strategije na primeru družinskega sirarstva v Bohinju. [Movement as Spatial Practices and Economic Strategies in Cheese Production at Family Farms in Bohinj.] Ars \& humanitas: 
Revija za umetnost in humanistiko / Journal of Arts and Humanities, Vol. 8, No. 1, pp. 38-57. DOI: 10.4312/ars.8.1.38-57.

Saunders, Nicholas J. 2001a. Matter and Memory in the Landscapes of Conflict: The Western Front 1914-1999. In: Barbara Bender \& Margot Winer (eds.) Contested Landscapes: Movement, Exile and Place. Oxford: Berg, pp. 37-53.

Saunders, Nicholas J. 2001b. Apprehending Memory: Material Culture and War, 19191939. In: John M. Bourne \& Peter H. Liddle \& Ian R. Whitehead (eds.) The Great World War, 1914-1945. Vol. 2: Who Won? Who Lost? London: HarperCollins, pp. 476-488. Available at http://www.academia.edu/2424285/, last accessed on 13 September 2018.

Saunders, Nicholas J. 2002. Excavating Memories: Archaeology and the Great War, 1914-2001. Antiquity, Vol. 76, No. 291, pp. 101-108. http://dx.doi.org/10.1017/ S0003598X00089857.

Saunders, Nicholas J. 2003. Trench Art: Materialities and Memories of War. Oxford: Berg. Saunders, Nicholas J. 2004. Material Culture and Conflict: The Great War, 1914-2003. In: Nicholas J. Saunders (ed.) Matters of Conflict: Material Culture, Memory and the First World War. London: Berg, pp. 5-25. Available at http://www.academia. edu/2358286/, last accessed on 13 September 2018.

Saunders, Nicholas J. 2013. Anthropology and Archaeology of the First World War. Cadernos do CEOM - Patrimônio, Memória e Identidade, Vol. 26, No. 38, pp. 1731. Available at https://bell.unochapeco.edu.br/revistas/index.php/rcc/article/ viewFile/1684/927, last accessed on 30 July 2018.

Tilley, Christopher Y. 1994. A Phenomenology of Landscape: Places, Paths and Monuments. Oxford: Berg.

Tilley, Christopher 2012. Walking the Past in the Present. In: Arnar Árnason \& Nicolas Ellison \& Jo Vergunst \& Andrew Whitehouse (eds.) Landscapes Beyond Land: Routes, Aesthetics, Narratives. New York \& Oxford: Berghahn, pp. 15-32.

UNESCO Tentative Lists. Available at https://whc.unesco.org/en/tentativelists/6077/, last accessed on 12 September 2018.

Wilson, Ross J. 2011. Tommifying the Western Front, 1914-1918. Journal of Historical Geography, Vol. 37, No. 3, pp. 338-347. http://dx.doi.org/10.1016/j.jhg.2011.01.001.

Winter, Jay 1998 [1995]. Sites of Memory, Sites of Mourning: The Great War in European Cultural History. Cambridge: Cambridge University Press.

Winter, Jay 2006. Remembering War: The Great War between Memory and History in the Twentieth Century. New Haven \& London: Yale University Press.

Woodward, Rachel 2014. Military Landscapes: Agendas and Approaches for Future Research. Progress in Human Geography, Vol. 38, No. 1, pp. 40-61. http://dx.doi. org/10.1177/0309132513493219. 